\title{
Peningkatan Keterampilan Berpikir Kritis dan Hasil Belajar Matematika Pada Siswa Kelas IV Melalui Penerapan Model Problem Based Learning
}

\author{
Dewi Pamungkas ${ }^{1 *}$, Mawardi ${ }^{2}$, Suhandi Astuti ${ }^{3}$
}

123 Pendidikan Guru Sekolah Dasar, Fakultas Keguruan dan Ilmu Pendidikan, Universitas Kristen Satya Wacana

\section{A R T I C L E I N F O}

Article history:

Received in revised form 09 March 2019

Accepted 15 April 2019

Available online 25 May 2019

\section{Kata Kunci: \\ Problem Based Learning, Keterampilan Berpikir \\ Kritis, Hasil Belajar, \\ Sekolah Dasar. \\ Keywords: \\ Problem Based Learning \\ Critical Thinking Skills, \\ Learning Outcomes, \\ Elementary Schools}

Received 10 February 2019

\begin{abstract}
A B S T R A K
Penelitian ini bertujuan untuk meningkatkan keterampilan berpikir kritis dan hasil belajar matematika siswa kelas 4 SDN Tingkir Tengah 02 dengan penerapan model pembelajaran Problem Based Learning (PBL). Penelitian yang dilakukan berjenis penelitian tindakan kelas model Jhon Elliot dengan empat tahapan yaitu perencanaan , pelaksanaan, observasi dan refleksi yang dilakukan dalam dua siklus. Setiap siklusnya terdiri dari tiga pertemuan. Perolehan data diperoleh dari instrumen berupa rubrik penilaian keterampilan berpikir kritis dan tes untuk hasil belajar Matematika. Subjek penelitian ini adalah kelas 4 SDN Tingkir Tengah 02 sebanyak 35 siswa. Teknis analisis data menggunakan teknik deskriptif komperatif anatar siklus. Hasil penelitian menujukkan temuan: (1) terdapat peningkatan keterampilan berpikir kritis siswa dari kondisi awal, siklus 1, dan siklus 2. Pada kondisi awal tingkat keterampilan berpikir kritis pada kategori kritis hanya $43 \%$, pada siklus $176 \%$, dan pada siklus 2 meningkat menjadi 97\%; (2) hasil belajar Matematika siswa juga mengalami peningkatan. Pada kondisi awal hanya $42 \%$ siswa yang mengalami ketuntasan, pada siklus 1
\end{abstract} meningkat menjadi $51 \%$ siswa yang tuntas, dan pada siklus 2 meningkat menjadi $68 \%$.

\section{A B S T R A C T}

This study aims to improve critical thinking skills and mathematics learning outcomes of 4th grade students at Middle Tingkir 02 Elementary School by applying the Problem Based Learning (PBL) learning molVel. The research carried out by Jhon Elliot's class action research type with four stages, namely planning, implementation, observation and reflection carried out in two cycles. Each cycle consists of three meetings. Data acquisition was obtained from instruments in the form of critical thinking skills assessment rubrics and tests for Mathematics learning outcomes. The subjects of this study were the 4th grade Tingkir Tengah Elementary School 02 as many as 35 students. The technical data analysis uses descriptive comparative techniques across cycles. The results showed: (1) there was an increase in students' critical thinking skills from the initial condition, cycle 1, and cycle 2. In the initial condition the critical thinking skills in the critical category were only $43 \%$, in the first cycle 76\%, and in the second cycle increased to 97\%; (2) Mathematics learning outcomes of students also increase. In the initial conditions only $42 \%$ of students experienced completeness, in cycle 1 it increased to $51 \%$ of students who completed it, and in cycle 2 it increased to $68 \%$.

\section{Pendahuluan}

Pasal 1 UU SISDIKNAS no. 20 tahun 2003 disebutkan bahwa Sistem Pendidikan Nasional adalah keseluruhan komponen pendidikan yang saling terkait secara terpadu untuk mencapai tujuan pendidikan nasional. Berangkat dari bunyi pasal ini dapat diketahui bahwa pendidikan adalah sistem yang merupakan suatu totalitas struktur yang terdiri dari komponen yang saling terkait dan secara bersama menuju kepada tercapainya tujuan (Soetarno, 2003: 2). Adapun komponen-komponen dalam pendidikan nasional antara lain adalah lingkungan, sarana-prasarana, sumberdaya, dan masyarakat. Komponen-komponen tersebut bekerja secara bersama-sama, saling terkait dan mendukung dalam mencapai tujuan pendidikan. Tujuan pendidikan nasional yang dirumuskan dalam UU SISDIKNAS adalah untuk mengembangkan 
potensi anak didik agar menjadi manusia yang beriman dan bertakwa kepada Tuhan Yang Maha Esa, berakhlak mulia, sehat, berilmu, cakap, kreatif, mandiri, dan menjadi warga Negara yang demokratis serta bertanggung jawab (Munirah, 2015).

Sasaran pokok atau utama dari pendidikan ialah manusia, yaitu menumbuhkan potensi-potensi yang ada dalam diri manusia agar terasah dan berkembang secara maksimal. Maka dari itu Kemendikbud No.20 tahun 2003 menyatakan bahwa pendidikan adalah usaha sadar dan terencana guna mewujudkan suatu kegiatan belajar mengajar, agar manusia dapat mengembangkan potensi dalam dirinya. Dengan adanya pendidikan yang ditempuh setiap orang diharapkan bahwa setiap potensi yang ada pada diri seseorang tersebut akan menjadi sesuatu yang bermanfaat kelak bagi dirinya sendiri, orang lain, nusa dan bangsa.

Pendidikan tidak lepas dari interasksi seorang pendidik dan peserta didik, dimana interaksi tersebut nantinya akan menjadi proses pembelajaran. Dengan pembelajaran tersebut nantinya peserta didik akan diasah setiap potensinya dengan dibimbing seorang pendidik, agar potensi yang ada dalam diri peserta didik akan berkembang maksimal dan berguna. (Mawardi, 2018:27) menyatakan bahwa pembelajaran adalah kegiatan seseorang yang memanipulasi sumber-sumber belajar menjadi proses belajar. Dengan hal tersebut tentunya peserta didik akan menerima segala informasi pada sumber-sumber yang ada dan dimanipulasi sebagai ilmu baru atau pengalaman dalam proses pembelajaran. Dan ketika proses pembelajaran berlangsung setiap individu akan mengalami perubahan tingkah laku, hal tersebut terjadi karena adanya interaksi pada proses pembelajaran.

Perubahan individu tersebut mencakup pada penguasaan pengetahuan, pengembangan pribadi, kemampuan sosial, serta kemampuan dalam berkerja. Maka dari itu pendidik harus memiliki tujuan untuk memberikan siswa pengalaman belajar yang berkesan dalam diri peserta didik. Sehingga dalam pengalaman belajar yang sudah dialaminya, peserta didik siap untuk berbaur dengan masyarakat dan menyelesaikan setiap permasalahan yang akan dihadapi setiap harinya.

(Susanto, 2014:10) menyatakan bahwa metematika merupakan cabang ilmu pengetahuan yang dapat meningkatkan kemampuan berpikir dan berpendapat, guna menyelsaikan segala masalah dalam kehidupan sehari-hari. Hal tersebut dinyatakan Susanto karena matematika adalah ilmu yang disusun secara deduktif agar mendidik dan mengajarkan anak berpikir logis. Karena matematika adalah ilmu yang berisikan berbagai ide gagasan, dan aturan guna meningkatkan kemampuan berpikir kritis dan logis. Untuk memecahkan masalah-maslah dalam kehidupan sehari-hari.

Pengertian berpikir kritis ditulis oleh Ennis (dalam Kuswana, 2011:19) merupakan cara berpikir yang wajar dan reaktif untuk menentukan fokus dalam menentukan apa yang harus dipercaya dan dilakukan. Tidak jauh beda dengan pendapat diatas, Jhon Dewey dalam (Fisher, 2009) juga menyatakan bahwa berpikir kritis secara esensial adalah sebuah proses berpikir yang aktif, dimana seseorang akan memikirkan suatu hal lebih mendalam, mengajukan berbagai pertanyaan menemukan informasi yang relevan untuk memutuskan suatu hal yang diperuntukkan untuk pengetahuannya sendiri.

Berpikir kritis adalah kemampuan yang sangat penting untuk menunjang keberhasilan pemahaman siswa, sehingga akan berdampak kedalam hasil belajar siswa. Maka dari itu seorang pendidik diharuskan untuk menyiapkan perencanaan yang matang dalam memilih model pembelajaran, agar siswa terpacu untuk meningkatkan kemampuan berpikir kritis dan hasil belajarnya. Dengan berdasarkan masalahmasalah yang dihadapi, dan pemilihan model pembelajaran yang inovatif.

Dari hasil observasi yang telah dilakukan di SDN Tingkir Tengah 02 masih banyak siswa yang malas belajar matematika, karena telah memiliki anggapan bahwa matematika adalah mata pelajaran yang sulit. Padahal wali kelas sudah berupaya untuk menciptakan pembelajaran yang menarik, agar siswa memiliki minat yang lebih untuk belajar matematika. Tetapi metode yang digunakan wali kelas kurang maksimal dalam pembelajaran, karena hanya menggunakan metode ceramah. Dari berbagai hal yang ditemukan dalam kegiatan prose belajar mengajar siswa serasa pasif karena hanya duduk diam dan mendengarkan. Siswa juga jarang untuk bertanya atau memberikan sebuah pendapat, bahkan jika guru melemparkan pertanyaan siswa lebih memilih merunduk agar tidak diminta menjawab. Maka dari itu dapat dikatakan keterampilan berpikir siswa masih dalam kategori rendah yang berpengaruh juga pada hasil belajar siswa. Berdasarkan masalah yang terjadi, ada salah satu cara untuk mengatasi hal tersebut yaitu dengan melakukan penerapan model Problem Based Learning.

Dari observasi diperoleh hasil sebagai berikut, 7 siswa (20\%) yang memiliki kemampuan berpikir kritis tinggi, 13 siswa (37,14\%) yang memiliki keterampilan berpikir kritis sedang, dan 15 siswa (42,86\%) yang memiliki keterampilan berpikir kritis randah. Data tersebut diambil dari 35 siswa jumlah siswa kelas 4 SDN Tingkir Tengah 02. Dari data diatas dapat kita kategorikan bahwa keterampilan berpikir siswa kelas IV SDN Tingkir Tengah 02 masih rendah, dan hal tersebut tentunya mempengaruhi hasil belajar siswa. Dengan proses wawancara didapatkan data awal bahwa hasil belajar siswa yang mencapai ketuntasan KKM 70 hanya 42\% dan 58\% diantaranya masih berada dibawah KKM. 
Salah satu cara yang dapat dilakukan untuk mengatasi masalah-masalah diatas adalah, dengan memilih model pembelajaran yang inovatif. Sesuai dengan kurikulum yang berlaku saat ini, yaitu kurikulum 2013 peneliti lebih memilih model Problem Based Learning (PBL) yang dianggap sesuai untuk mengatasi masalah minat belajar matematika siswa. Problem Based Learning sebagai rangkaian aktivitas belajar siswa menekankan pada proses penyelsaian masalah yang dihadapi dengan cara ilmiah (Sanjaya, 2016). Maka dari itu model tersebut dapat diartikan sebagai model pembelajaran kontuktivisme berdasarkan situasi nyata, yang menekankan kepada proses penyelsaian masalah dengan membangun mental berpikir kritis siswa. Sehingga siswa pada akhirnya dapat mengali lebih lanjut masalah yang ada, dan dapat memecahkanya dengan cara berpikir kritis. Dan dengan keterampilan berpikir kritis siswa tersebut tentunya pada proses pembelajaran akan berdampak kepada hasil belajar siswa.

Pembelajaran PBL merupakan model pembelajaran yang memacu siswa untuk berpikir kritis dan kreatif serta mengembangkan ide-ide sehingga bisa memecahkan masalah melalui eksperimen Duch, dkk dalam Abidin (2013: 160). Eksperimen yang dimaksud adalah pembelajaran dengan menggunakan alat dan bahan baik secara individu maupun kelompok sehigga siswa dapat mengembangkan ide-ide siswa (Suriana, 2016). Problem Based Learning memiliki lima sintaks yaitu Meeting the Problem, Problem Analysis and Learning Issue, Problem based and Reporting, Solution Presentation and Reflection, dan Overview, Integration, and Evaluation (Sutanto, 2018).

Problem Based Learning (PBL), merupakan salah satu model pembelajaran pembelajaran yang menuntut aktivitas mental siswa untuk memahami suatu konsep pembelajaran melalui situasi dan masalah yang disajikan pada awal pembelajaran dengan tujuan untuk melatih siswa menyelesaikan masalah dengan menggunakan pendekatan pemecahan masalah [2]. Siswono (2009 dalam Utomo, 2014) menyatakan bahwa ada hubungan antara pemecahan masalah dengan kemampuan berpikir kreatif karena berpikir kreatif merupakan suatu proses yang digunakan ketika mendatangkan (memunculkan) suatu ide baru dengan menggabungkan ide-ide yang sebelumnya dilakukan.

(Sastrawati, E. \& Rusdi, 2011) menyatakan bahwa pembelajaran model PBL membuat perubahan dalam proses pembelajaran khususnya dalam segi peranan guru. Guru tidak hanya berdiri di depan kelas dan berperan sebagai pemandu siswa dalam menyelesaikan masalah dengan memberikan langkahlangkah penyelesaian yang sudah jadi. Dalam model PBL guru dituntut untuk menfasilitasi diskusi, memberikan pertanyaan, dan membantu siswa untuk menjadi lebih sadar akan proses pembelajaran(Fauzan, 2017).

Menurut Moffit (dalam Rahayu, 2016) Pembelajaran Berbasis Masalah atau Problem Based Learning adalah suatu pendekatan pembelajaran yang menggunakan masalah dunia nyata sebagai suatu konteks bagi siswa untuk belajar tentang berpikir kritis dan keterampilan pemecahan masalah, serta untuk memperoleh pengetahuan dan konsep yang esensi dari materi pelajaran.

Menurut Murniati \& Hermawan (2017:1 dalam Dwi, 2017) Problem Based Learning merupakan model pembelajaran yang menuntut peserta didik untuk mempelajari penemuan berdasarkan perencanaan dan prinsip yang sudah ditentukan atau disebut juga discovery learning dan sekaligus memiliki keterampilan untuk memecahkan masalah.

Menurut Cahyo (2013: 283), pembelajaran berdasarkan masalah atau Problem Based Learning (PBL) adalah suatu model pembelajaran yang didasarkan pada prinsip menggunakan masalah sebagai titik awal akusisi dan integrasi pengetahuan baru. Menggunakan model Problem Based Learning (PBL) siswa dapat berfikir secara kritis untuk memecahkan suatu masalah dan dapat mengetahui pengetahuan baru. Jadi dengan model Problem Based Learning (PBL) siswa akan dihadapkan pada masalah dalam proses pembelajaran dengan demikian akan membuat siswa aktif karena merasa tertantang untuk bekerjasama untuk mengasah kemampuan menyelesaikan masalah dengan cara mengumpulkan dan menganalisis data agar dapat memecahkan masalah serta menemukan solusinya (Nuraini, 2017).

Model PBL merupakan suatu model pembelajaran yang difokuskan pada pengalaman pembelajaran yang diatur meliputi penyelidikan dan pemecahan masalah khususnya masalah yang berkaitan dengan kehidupan sehari-hari (Fitria. dkk, 2013). Model PBL ini menyebabkan motivasi dan rasa ingin tahu menjadi meningkat juga membuat perubahan dalam pembelajaran khususnya dalam segi peranan guru. Guru tidak hanya berdiri di depan kelas dan berperan sebagai pemandu siswa dalam menyelesaikan permasalahan dengan memberikan langkah-langkah penyelesaian yang sudah jadi, melainkan guru berkeliling kelas memfasilitasi diskusi, memberikan pertanyaan, dan membantu siswa untuk menjadi lebih sadar akan pentingnya pembelajaran (Fachri, 2014)

\section{Metode}

Penelitian yang digunakan adalah Penelitian Tindakan Kelas (PTK). Tampubolon (2013:16) menyatakan penelitian tindakan kelas merupakan penelitian yang reflektif dan bersiklus. Penelitian ini dilakukan secara kolaboratif sekelompok orang yaitu wali kelas dan peneliti. Dalam penelitian tindakan 
kelas model Jhon Elliot ini ada empat tahapan yaitu perencanaan, pelaksanaan, observasi, dan refleksi yang dilaksanakan dua siklus dan dalam setiap siklusnya terdiri dari tiga pertemuan. Penelitian dilaksanakan pada bulan Mei 2019 di SDN Tingkir Tengah 02.

Teknik pengumpulan data menggunakan angket untuk mengetahui keterampilan berpikir kritis siswa. Dan tes tertulis berbentuk pilihan ganda untuk mengukur hasil belajar materi bangun datar. Pada penelitian tindakan kelas ini dapat dikatakan berhasil apabila dapat meningkatkan keterampilan berpikir kritis dan hasil belajar pada mata pelajaran matematika pada siswa kelas IV SD Tingkir Tengah. Apabila terjadi peningkatan sebesar $\geq 60 \%$ dari seluruh peserta didik (secara klasikal), maka dapat dikategorikan bahwa penelitian meningkatkan keterampilan berpikir kritis dan hasil belajar matematika kelas IV SDN Tingkir Tengah 2 menggunakan model PBL berhasil.

\section{Hasil dan Pembahasan}

Berdasarkan hasil penelitian dengan penerapan model Promlem Based Learningi dapat dilihat perbandingannya dari hasil penilaian keterampilan berpikir kritis dan hasil belajar siswa dari kondisi awal, siklus 1 dan siklus 2 . Hal tersebut dapat dilihat pada tabel dan diagram yang ada di bawah ini.

Tabel 1. Rangkuman Keterampilan Berpikir Kritis Siswa.

\begin{tabular}{lccc}
\hline \multicolumn{1}{c}{ Kategori Berpikir Kritis } & Kondisi Awal & Siklus 1 & Siklus 2 \\
\hline Sangat Tinggi & $6 \%$ & $12 \%$ & $21 \%$ \\
\hline Sedang & $37 \%$ & $64 \%$ & $76 \%$ \\
\hline Kurang & $46 \%$ & $24 \%$ & $3 \%$ \\
\hline Sangat Kurang & $11 \%$ & $0 \%$ & $0 \%$ \\
\hline Rata-Rata & $\mathbf{4 9}$ & $\mathbf{6 0}$ & $\mathbf{6 7}$ \\
\hline Mean & $\mathbf{6 8}$ & $\mathbf{6 0}$ & $\mathbf{6 9}$ \\
\hline Skor Tertinggi & $\mathbf{8 1}$ & $\mathbf{8 0}$ & $\mathbf{9 0}$ \\
\hline Skor Terrndah & $\mathbf{1 9}$ & $\mathbf{4 4}$ & $\mathbf{4 5}$ \\
\hline
\end{tabular}

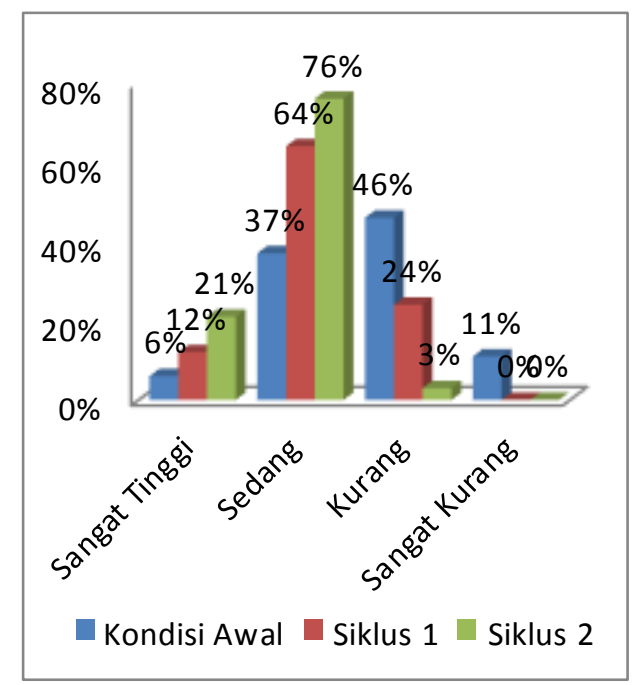

Gambar 1. Grafik Perbandingan Keterampilan Berpikir Kritis Siswa.

Hasil dari penelitian yang dilakukan di kelas 4 SDN Tingkir Tengah 02, dapat dilihat pada tabel 1 dan diagram 2 diatas. Dapat dilihat dengan jelas bahwa pada tabel 1 dan diagram 1 menujukkan keterampilan berpikir kritis siswa semakin meningkat pada setiap siklusnya. Peningkatan keterampilan berpikir kritis siswa dapat dilihat dari tabel 1 yaitu rata-rata pada kondisi awal, siklus 1, dan siklus 2 selalu meingkat. Pada kondisi awal rata-rata yang diperoleh dari hasil angket berpikir kritis hanyalah 49, di siklus 1 meningkat rata-rata keterampilan berpikir kritis menjadi 60, dan pada siklus yang terakhir yaitu siklus 2 rata-rata keterampilan berpikir kritis siswa naik 7 menjadi 67. Dengan meningkatnya keterampilan berpikir kritis siswa tentunya akan berpengaruh terhadap hasil belajar matematika siswa.

Berikut ini adalah hasil perbandingan dari hasil belajar matematika siswa dari kondisi awal, siklus 1, dan siklus 2 yang akan disajikan dengan tabel dan diagram di bawah ini : 
Tabel 2. Rangkuman Hasil Belajar Matematika Siswa.

\begin{tabular}{lccc}
\hline \multicolumn{1}{c}{ Kategori } & Kondisi Awal & Siklus 1 & Siklus 2 \\
\hline Tuntas & $42 \%$ & $51 \%$ & $68 \%$ \\
\hline Tidak Tuntas & $58 \%$ & $49 \%$ & $32 \%$ \\
\hline Rata-Rata & & $\mathbf{6 9}$ & $\mathbf{7 6}$ \\
\hline Median & & $\mathbf{7 3}$ & $\mathbf{7 7}$ \\
\hline Skor Tertinggi & & $\mathbf{8 7}$ & $\mathbf{1 0 0}$ \\
\hline Skor Terrndah & & $\mathbf{4 7}$ & $\mathbf{5 3}$ \\
\hline
\end{tabular}

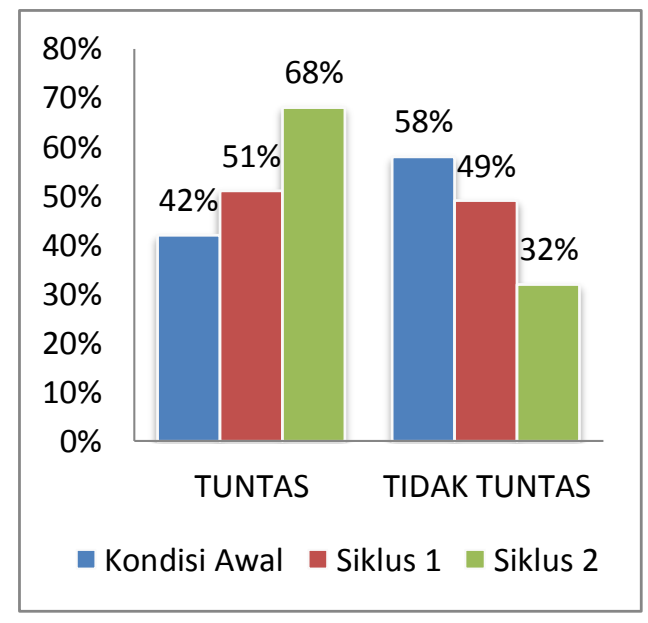

Gambar 2. Grafik Perbandingan Ketuntasan Hasil Belajar Matematika Siswa

Dari tabel 2 dan diagram 2 diatas dapat dilihat bahwa ketuntasan siswa kelas 4 SDN Tingkir Tengah 02 dari kondisi awal, siklus 1, dan siklus 2 mengalami peningkatan. Hal tersebut dapat dilihat dari prosentase ketuntasan pada setiap siklusnya. Pada kondisi awal didapat ketuntasan dengan prosentase $42 \%$, dan pada siklus 2 meningkat ketuntasannya menjadi 51\%, dan pada siklus 2 meningkat menjadi $68 \%$.

Peningkatan keterampilan berpikir kritis siswa dan hasil belajar matematika siswa juga dipengaruhi oleh aktivitas yang dilakukan guru dalam pembelajaran. Perbandingan aktivitas guru pada siklus 1 dan 2 dapat dilihat dari tebel dan diagram dibawah ini :

Tabel 3. Perbandingan Aktivitas Guru Siklus 1 dan Siklus 2

\begin{tabular}{cccc}
\hline \multirow{2}{*}{ No } & Aktivitas Guru & $\begin{array}{c}\text { Persentase Aktivitas Guru } \\
\text { Siklus 1 }\end{array}$ & $\begin{array}{c}\text { Persentase Aktivitas Guru } \\
\text { Siklus 2 }\end{array}$ \\
\hline 1 & Terlaksana Model & $80 \%$ & $100 \%$ \\
2 & Tidak Terlaksana Model & $20 \%$ & $0 \%$ \\
\hline & Jumlah & $\mathbf{1 0 0 \%}$ & $\mathbf{1 0 0 \%}$ \\
\hline
\end{tabular}

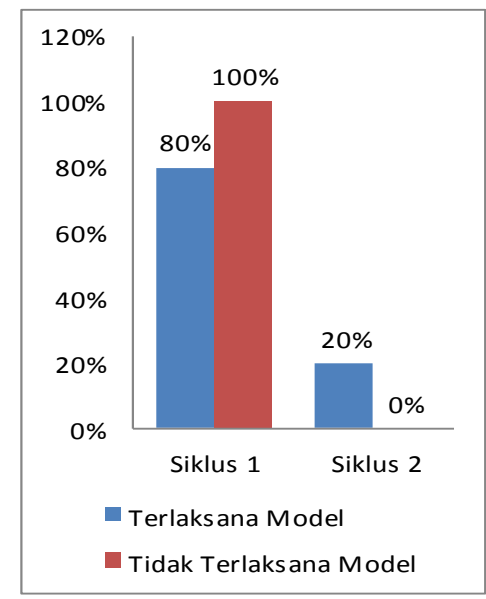

Gambar 3. Grafik Aktivitas Guru Siklus 1 dan Siklus 2 
Berdasarkan Tabel 3 dan Diagram 3 aktivitas guru pada siklus 1 dan siklus 2 mengalamipeningkatan dari aktivitas guru pada siklus pertama hanya $80 \%$ menjadi sempurna terlaksana pada siklus 2 yaitu 100\% terlaksana. Peningkatan keteampilan berpikir kritis siswa dilihat dari hasil observasi yang telah dilakukan dari kondisi awal, siklus 1 dan siklus 2. Pada kondisi awal belum ada peneraapan model pembelajaran Problem Based Learning yang dilakukan, dan hanya 43\% siswa yang memiliki keterampilan berpikir kritis. Pada siklus 1, peneliti telah menerapakan model pembelajaran Problem Based Learning mekipun penerapnnya kurang sempurna, siswa yang memiliki keterampilan berpikir kritis meningkat menjadi 46\%. Pada siklus 2 guru memperbaiki segala aktivitasnya dalam penerapan model Problem Based Leraning pada siklus sebelumnya, dan pada siklus 2 guru melakukan penerapan model Problem Based Learning dengan sempurna dengan pencapaian 100\% terlaksana. Hal ini berpengaruh kepada meningkatnya keterampilan beroikir kritis siswa yang menjadi 91\%.

Semakin meningkatnya keterampilan berpikir kritis siswa, tentunya ketuntasan hasil belajar matematika siswa semaikin meningkat. Hal ini dibuktikan dengan meningkatnya ketuntasan hasil belajar siswa dari kondisi awal, siklus 1, dan siklus 2. Pada kondisi awal guru menyatakan bahwa hanya $42 \%$ siswa yang tuntas dalam KKM, lalu pada siklus 1 setelah mengalami penerapan model Problem Based Learning meningkat ketuntasan siswa menjadi 51\%, dan pada siklus 2 meningkat lagi menjadi 68\%.

Berdasarkan uraian di atas, penerapan model Problem Based Learning pada siswa kelas SDN Tingkir Tengah 02 dapat meningkatakan keterampilan berpikir keritis siswa dan hasil belajar matematika. Hasil penelitian ini memperkuat penelitian yang terdahulu yaitu penerapan model Problem Based Learning (PBL) dapat meningkatkan keterampilan berpikir kritis siswa seperti yang dilakukan oleh Riska, Johman, dan Kartika (2014) dalam (Nurun \& Yunin \& Wardan Suyanto, 2014). Penelitian ini juga menujukkan bahwa keberhasilan penerapan model Problem Based Learning (PBL) dapat meningkatkan hasil belajar matematika siswa. Hal tersebut memperkuat penelitian yang telah dilakukan oleh (Mustamilah, 2014), (Fauzia, 2015).

Hal yang membedakan penelitian ini dengan penelitian sebelumnya yaitu penelitian ini mengukur keterampilan berpikir kritis siswa dan hasil belajar matematika siswa pada materi pengukuran sudut dengan busur derajat menggunakan model pembelajaran Problem Based Learning. Pada penerapan model Problem Based Learning ini, guru dapat memudahkan siswa untuk memberikan pengalaman langsung kepada siswa bagaimana cara proses pemecahan masalah sehari-hari sehingga pembelajaran akan lebih bermakna sesuai dengan materi yang telah diajarkan pada siswa kelas IV SDN Tingkir Tengah 02.

\section{Simpulan dan Saran}

Berdasarkan hasil penelitian yang telah dilaksanakan pada kelas IV SDN Tingkir Tengah 02, dapat disimpulkan bahwa: (1) penerapan model Problem Based Learning pada pembelajaran dapat meningkatkan keterampilan berpikir keritis siswa, hal tersebut ditunjukkan dengan meningkatnya keterampilan berpikir kritis dari awal kondisi, siklus 1, dan siklus 2. Pada kondisi awal sebelum diterapkan model Problem Based Learning keterampilan berpikir kritis siswa 43\%, pada siklus 1 setelah mendapatkan penerapan model Problem Based Learning meningkat menjadi 76\%, dan pada siklus 2 meningkat menjadi 97\%. (2) dengan meningkatnya keterampilan berpikir kritis siswa, hasil belajar matematika siswa juga mengalami peningkatan pada awal kondisi, siklus 1, dan siklus 2. Pekembangan itu ditunjukkan pada kondisi awal hanya 48\% siswa yang mengalami ketuntasan, pada siklus 1 meningkat menjadi 51\% siswa yang tuntas, dan pada siklus 2 meningkat menjadi $68 \%$ siswa yang tuntas.

Adapun saran yang dapat diberikan berdasarkan hasil dan pembahasahan penelitian ini adalah sebagai beikut: 1) guru hendaknya dapat mengembangkan potensi yang dimiliki khususnya dalam mengembangkan model pembelajaran sehingga siswa tidak mersa jenuh dalam pemebalajaran dan hasil belajar mengalami peningkatan. Salah satunya adalah mengemabngkan model PBL. 2) Kepala sekolah hendaknya lebih memberikan kesempatan kepada guru untuk meningkatkan potensi yang mereka miliki misalnya melalui FGD. 3) Peneliti lain bisa menggunakan penelitian ini sebagai referensi dan tentunya dapat meningkatkan kualitas dari penelitian yang dilakukannya.

\section{Daftar Rujukan}

Abidin, Y. (2013). Desain Sistem Pembelajaran dalam Konteks Kurikulum 2013. 2014. Bandung: Refika Aditama.

Cahyo, A. N. (2013). Panduan Aplikasi Teori-Teori Belajar Mengajar Teraktual dan Terpopuler. Yogyakarta: DIVA Press.

Dwi, E. (2017). Pengembangan Model Problem Based Learning Dan Blended Learning Dalam Pembelajaran Pemantapan Kemampuan Profesional Mahasiswa. Jurnal Universitas Muhammadiyah Semarang, 13(2).

Fachri, M. (2014). Penerapan Model Problem Based Learning (Pbl) Untuk Meningkatkan Hasil Belajar 
Siswa Pada Materi Panjang Garis Singgung Persekutuan Dua Lingkaran Di Kelas VIII Smp Negeri 19 Palu. Jurnal Elektronik Pendidian Matematika Tadulako, 2(1).

Fauzan, M. (2017). Penerapan Model Problem Based Learning Pada Pembelajaran Materi Sistem Tata Surya Untuk Meningkatkan Hasil Belajar Siswa. Jurnal Pendidikan Sains Indonesia, 5(1), 27-35.

Fauzia, H. A. (2015). Penerapan Model Pembelajaran Problem Based Learning untuk Meningkatkan Hasil Belajar Matematika SD. Primary: Jurnal Pendidikan Guru Sekolah Dasar, 7(1), 40-47.

Fisher, A. (2009). Berpikir Kritis Sebuah Pengentar. Jakarta: Erlangga.

Fitria. dkk. (2013). Penggunaan Model Problem Based Learning DenganMultirepresentasi Pada Usaha dan Energi di SMA. Jurnal Untan. Retrieved from http://jurnal.untan.ac.id/index.php/jpdpb/article/download/3723/3728

Kuswana, W. S. (2011). Taksonomi Berpikir. Bandung: PT Remaja.

Mawardi, M. (2018). Merancang Model dan Media Pembelajaran. Scholaria: Jurnal Pendidikan Dan Kebudayaan, 8(1), 26-40.

Munirah. (2015). Sistem Pendidikan di Indonesia: Antara Keinginan dan Realita. Jurnal Fakultas Tarbiyah Dan Keguruan UIN Alauddin Makassar, 2(2), 233-245.

Mustamilah, M. (2014). Peningkatan Keterampilan Proses dan Hasil Belajar Menggunakan Model Problem Based Learning pada Sub Tema Merawat Tubuhku Siswa Kelas 1 SD Negeri 1 Gosono-Wonosegoro. Scholaria: Jurnal Pendidikan Dan Kebudayaan, 5(1), 92-102.

Nuraini, F. (2017). Penggunaan Model Problem Based Learning (PBL) Untuk Meningkatkan Hasil Belajar IPA Siswa Kelas 5 SD. E-Jurnal Mitra Pendidikan, 1(4).

Nurun \& Yunin \& Wardan Suyanto. (2014). Penerapan Model Problem-Based Learning Untuk Meningkatkan Keterampilan Berpikir Kritis dan Hasil Belajar Siswa. Yogyakarta: Jurnal Pendidikan Vokasi.

Rahayu, I. (2016). Penerapan Model Pembelajaran Problem Based Learning Untuk Meningkatkan Sikap Kerja Sama Dan Hasil Belajar Siswa Pada Pembelajaran Tematik Di Sdn Kencana Indah Ii . Jurnal Pendidikan Guru Sekolah Dasar STKIP Subang, 1(2).

Sanjaya, W. (2016). Strategi Pembelajaran Beorientasi Setandar Proses Pendidikan. Jakarta: Kencana.

Sastrawati, E. \& Rusdi, M. \& Syamsurizal. (2011). Problem Based Learning, Strategi Metakognisi, dan Ketrampilan Berfikir Tingkat Tinggi Siswa. Jurnal Tekno-Pedagogi, 1(2), 1-14.

Soetarno. (2003). Sumber Daya Pendidikan Dengan Pendekatan Sistem. Makalah Pendidikan. Surakarta: Universitas Muhammadiyah Surakarta.

Suriana. (2016). Penerapan Model Problem Based Learning (Pbl) Berbasis Eksperimen Untuk Meningkatkan Pemahaman Konsep Usaha Dan Energi Ditinjau Dari Gaya Berpikir Siswa Di Man Rukoh Banda Aceh. Jurnal Pendidikan Sains Indonesia, 4(2), 127-139.

Susanto, A. (2014). Metode Penelitian Pendidikan. Jakarta: Kencana.

Sutanto, W. (2018). Penggunaan Problem Based Learning untuk Meningkatkan Kemampuan Berpikir Kreatif dalam Pembelajaran Biologi Peserta Didik Kelas VII F di Salah Satu SMP Negeri di Surakarta. Jurnal Pendidikan Biologi BIOEDUKASI.

Utomo, T. (2014). Pengaruh Model Pembelajaran Berbasis Masalah (Problem Based Learning) Terhadap Pemahaman Konsep dan Kemampuan Berpikir Kreatif Siswa (Siswa Kelas VIII Semester Gasal SMPN 1 Sumbermalang Kabupaten Situbondo Tahun Ajaran 2012/2013). JURNAL EDUKASI UNEJ. 